\title{
PENERAPAN METODE GALLERY WALK TERHADAP KREATIVITAS SISWA PADA MATERI PENCEMARAN LINGKUNGAN DI KELAS X SMA NEGERI 1 GEGESIK
}

\author{
Retno Rakhmayanti ${ }^{1)}$, Anna Fitri Hindriana ${ }^{2)}$, Handayani ${ }^{3)}$ \\ ${ }^{1}$ Mahasiswa Program Studi Pendidikan Biologi FKIP, Universitas Kuningan \\ Email : retnorakhmayanti95@gmail.com \\ ${ }^{23}$ Dosen Program Studi Pendidikan Biologi FKIP, Universitas Kuningan \\ Email : anna@uniku.ac.id \\ Email : handayani@uniku.ac.id
}

APA Citation: Rakhmayanti, R., Hindriana, A.F., \& Handayani, H. (2018). Penerapan Metode Gallery Walk Terhadap Kreativitas Siswa Pada Materi Pencemaran Lingkungan Di Kelas X SMA Negeri 1 Gegesik. Quagga: Jurnal Pendidikan dan Biologi, 10(2), 19-24. doi: 10.25134/quagga.v10i2.1252.

Received: 08-06-2018

Accepted: $29-07-2018$

Published: 30-07-2018

\begin{abstract}
Abstrak: Tujuan penelitian ini adalah untuk mengetahui pengaruh penerapan metode Gallery Walk terhadap kreativitas siswa dengan menggunakan metode True Eksperimen post-test Only Control Design. Penelitian ini juga menggunakan Peer Assesment untuk menilai proses pembuatan produk antar teman, Angket digunakan untuk mengetahui respon siswa terhadap metode pembelajaran Populasi penelitian adalah seluruh siswa kelas X IPA SMA Negeri 1 Gegesik Tahun ajaran 2016/2017 yang berjumlah 194 siswa. Pengambilan sampel dilakukan dengan menggunakan Cluster Random Sampling, dibagi menjadi 2 kelompok kelas, yaitu kelas metode Gallery Walk sebanyak 40 siswa dan kelas metode Proyek sebanyak 40 siswa. Instrumen yang digunakan adalah lembar observasi penilaian kreativitas produk, lembar observasi penilaian antar teman dan angket. Hipotesis diuji menggunakan uji statistik nonparametrik wilcoxon, Peer Assesment dan angket menggunakan presentasi hasil . Hasilpenelitian menunjukkan bahwa nilai uji wilcoxon adalah $R^{\#} 820>Z 7,7$ yang artinya ada pengaruh penerapan metode Gallery Walk terhadap kreativitas siswa. Hasil Peer Assesment menunjukkan presentasi $100 \%$ untuk semua indikator pada kelas ekspeimen yang artinya peer assesment ini sangat baik digunakan pada metode Gallery Walk. Sedangkan untuk hasil Angket menunjukkan presentasi $90 \%$ untuk proses pembelajaran, 88,75\% untuk kecocokan Metode Galley Walk terhadap materi, 87,5\% untuk kelebihan metode Gallery Walk, 5\% untuk kekurangan metode Gallery Walk.
\end{abstract}

Kata kunci : Gallery Walk, Kreativitas

Abstract: The purpose of this study was to determine the effect of applying the Gallery method Walk to the creativity of students by using the True Experiment Post-test Only Control Design method. This study also uses Peer Assessment to assess the process of making products between friends, Questionnaire is used to determine student responses to learning methods The study population was all students of class X IPA Gegesik 1 Public High School 2016/2017 academic year totaling 194 students. Sampling was done using Cluster Random Sampling, divided into 2 groups of classes, namely the Gallery Walk method class of 40 students and the Project method class as many as 40 students. The instruments used were observation sheets for product creativity assessment, observation sheet assessment between friends and questionnaires. The hypothesis was tested using the nonparametric Wilcoxon statistical test, Peer Assessment and questionnaire using presentation results. The resultsshowed that the Wilcoxon test value was $R^{\#} 820>Z 7.7$ which means that there was an effect of applying the Gallery Walk method to student creativity. Peer Asses results show a 100\% presentation for all indicators in the experimental class, which means that the peer assessment is very well used on the Gallery Walk method. While the results of the questionnaire showed a presentation of 90\% for the learning process, $88.75 \%$ for the compatibility of the Galley Walk Method for the material, $87.5 \%$ for the advantages of the Gallery Walk method, $5 \%$ for the lack of the Gallery Walk method.

Keywords: Gallery Walk, Creativity

\section{PENDAHULUAN}

Pendidikan adalah suatu proses sadar dan terencana dari setiap individu maupun kelompok untuk membentuk pribadi yang lebih baik
(Sugiharto dalam Fathurrohman, 2015:23). Hal ini juga sesuai dengan tujuan pendidikan nasional yang terdapat di Undang-Undang SISDIKNAS No. 20 tahun 2003 yang 
menyatakan bahwa pendidikan merupakan usaha sadar dan terencana untuk mewujudkan suasana belajar dan proses pembelajaran agar peserta didik secara aktif mengembangkan potensi dirinya untuk memiliki kekuatan spiritual keagamaan, pengendalian diri, kepribadian, kecerdasan, akhlak mulia, serta keterampilan yang diperlukan dirinya dan masyarakat. Proses pendidikan dialami siswa sepanjang hayat serta dapat berlaku di mana pun dan kapan pun. Proses pembelajaran merupakan integrasi dari berbagai elemen pembelajaran yang meliputi pendidik, peserta didik, kurikulum, dan metode pembelajaran (Alzarnudi dalam Fathurrohman, 2015:19)

Topik-topik biologi merupakan salah satu kajian yang dipelajari secara formal pada berbagai jenjang pendidikan. Seharusnya, biologi merupakan salah satu mata pelajaran sains yang dapat mengembangkan keterampilan berpikir dan juga mengembangkan kreativitas dalam bentuk keterampilan proses sains (Alzarnudi dalam Fathurrohman, 2015:22). Begitu pula Standar Kompetensi Lulusan (SKL) Sekolah Menengah Atas yang menyatakan bahwa mata pelajaran bilogi bertujuan membentuk peserta didik yang memiliki kemampuan berpikir logis, kritis, kreatif, dan inovatif dalam pengambilan keputusan serta dapat membangun dan menerapkan informasi dan pengetahuan secara logis, kritis, kreatif, dan inovatif (BSNP, 2006:VI). Kreativitas dalam pembelajaran biologi menekankan pada pengembangan aspek psikomotor siswa selain aspek sikap dan kognitif (Benjamin S Bloom dalam Fathurrohman, 2015: 24).

Berdasarkan hal tujuan pembelajaran biologi tersebut menunjukkan bahwa pembelajaran biologi yang perlu dilakukan saat ini tidak hanya menekankan pada pemahaman konsep oleh siswa, tetapi sangat perlu menekankan pada pembekalan aspek kreativitasnya. Keberhasilan pembelajaran biologi dapat dilihat dari tingkat pemahaman, penguasaan materi dan kreativitas siswa (Ali dan Asrori, 2012 : 54). Oleh karena itu, dibutuhkan kemampuan seorang guru dalam mengelola kelas yang baik agar siswa dapat memahami materi biologi secara utuh sekaligus mengembangkan kreativitas siswa. Kreativitas siswa dapat dikembangkan dengan menerapkan kegiatan-kegiatan atau pemberian tugas yang dapat mengembangkan daya imajinasi seperti mengadakan observasi, pembuatan produk, mempraktekkan dan mendemonstrasikan sesuatu (Ali dan Asrori, 2012 : 43).Pada kenyataannya kreativitas siswa pada pembelajaran biologi masih rendah. Faktor yang mempengaruhi kreativitas antara lain: 1) kurangnya pemahaman konsep-konsep biologi dalam kaitannya dengan kehidupan sehari-hari; 2) tidak adanya keterampilan proses untuk mengembangkan pengetahuan dan ide; 3) kurangnya minat untuk mengenal dan mempelajari benda-benda yang ada di lingkungan sekitar; 4) bersikap tidak ingin tahu; 5) tidak dapat memecahkan masalah dalam kehidupan sehari-hari yang berkaitan dengan penerapan konsep biologi; 6) tidak mampu menggunakan teknologi sederhana yang berguna untuk memecahkan masalah yang ditemui dalam kehidupan sehari-hari; 7) kurangnya rasa cinta terhadap alam sekitar (Depdikbud dalam Fathurrohman, 2015:25).

Begitu pula berdasarkan hasil wawancara dengan guru Biologi di SMA Negeri 1 Gegesik diperoleh gambaran bahwa kreativitas siswa di kelas $\mathrm{X}$ belum dikembangkan secara optimal yang ditandai dengan : 1) siswa kurang berani mengungkapkan ide, gagasan ataupun pendapat; 2) siswa kesulitan dalam mengembangkan pengetahuan yang diperoleh dari pembelajaran; 3) siswa belum mampu menarik kesimpulan dari materi yang disampaikan; 4) siswa sulit berkonsentrasi; 5) kemampuan adaptasi siswa rendah; 6) rasa ingin tahu rendah; 7) siswa mudah bosan; 8) sulit menemukan solusi permasalahan. Proses pembelajarannya masih didominasi dengan metode ceramah, guru lebih aktif dan siswa cenderung pasif. Metode pembelajaran seperti ini akan berdampak pada rendahnya keaktifan dan kreativitas siswa (Depdikbud dalam Fathurrohman, 2015:24).

Saat ini kreativitas siswa penting untuk dikembangkan dalam pembelajaran biologi, sehingga dibutuhkan metode pembelajaran yang mampu melibatkan siswa secara langsung. Oleh karena itu, solusi untuk mengatasi masalah tersebut dengan menerapkan berbagai metode pembelajaran yang bervariasi. Salah satunya dengan menggunakan metode Gallery Walk untuk meningkatkan kreativitas siswa.

Metode Gallery Walk atau metode pameran digunakan untuk memberikan kesempatan kepada siswa untuk menyajikan dan menjelaskan apa yang telah dipelajarinya(Haryono, 2013:76). Pameran yang dimaksud dapat berupa pameran kelas atau pameran sekolah dengan menampilkan beragam hasil karya siswa. Dalam pembelajaran IPA, pameran dapat menampilkan grafik, model, alat peraga, gambar, tanaman dan hasil karya lainnya yang dibuat oleh siswa 
(Haryono, 2013:76). Metode Gallery Walk ini lebih menekankan kepada siswa untuk berperan aktif dan berperan secara langsung dalam proses pembelajaran. Hal ini sesuai dengan hasil penelitian Persada (2015) yang menunjukkan bahwa kreativitas siswa sangat baik dengan penggunaan metode Gallery Walk. Beranjak dari permasalahan tersebut penulis bermaksud melakukan penelitian dengan judul "Penerapan Metode Gallery Walk terhadap Kreativitas Siswa pada Materi Pencemaran Lingkungan di Kelas X SMA Negeri 1 Gegesik".

\section{METODOLOGI PENELITIAN}

Penelitian ini bertujuan untuk mengetahui pengaruh penerapan metode Gallery Walk terhadap kreativitas siswa pada materi pencemaran lingkungan. Peneliti memberikan perlakuan yang berbeda terhadap dua kelas sampel,yaitu kelas eksperimen yang menggunakan metode Gallery Walk dan kelas kontrol menggunakan metode proyek. Angket respon siswa dan peer assesment digunakan sebagai data pendukung untuk pelaksanaan metode Gallery Walk. Data dari kedua sampel digunakan untuk menjawab hipotesis dengan menggunakan rubrik penilaian produk yang terdiri dari tiga indikator kemampuan kreativitas yaitu kebaruan (novelty), keluwesan (flexibility) dan kerincian (elaboration).

Metode penelitian yang digunakan dalam penelitian ini adalah metode quasieksperimen dengan Post-test Only Control Design. Adapun rancangan desain penelitiannya sebagai berikut :

Tabel 1. Desain Penelitian Post- test Only

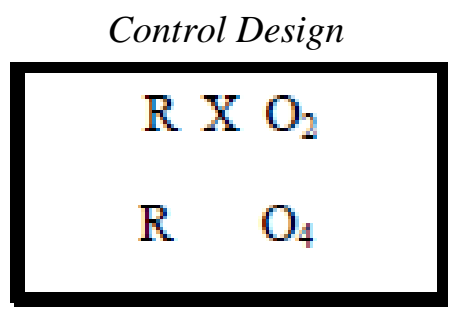

Populasi dalam penelitian ini adalah kelas $\mathrm{X}$ SMA Negeri 1 Gegesik yang berjumlah 194 siswa. Sampel yang digunakan dalam penelitian ini diambil secara cluster random sampling didapatkan dua kelas yaitu satu kelas eksperimen dan satu kelas kontrol dengan jumlah 80 siswa.

Penelitian ini dilakukan pada KD Pencemaran Lingkungan. Adapun indikator yang menjadi target adalah pemanfaatan limbah atau barang-barang yang sudah tidak terpakai. Kegiatan pembelajaran dilakukan selama 2 kali pertemuan, Pertemuan pertama siswa berdiskusi merancang mengenai produk yang akan dibuat, bahan dan alat yang akan digunakan. Pertemuan kedua guru membimbing dan memantau setiap kelompok dalam pembuatan produk, proses pameran serta penilaian produk dari setiap kelompok. Adapun produk yang ditampilkan diantaranya : poster pencemaran lingkungan dari barang bekas, jam dari barang bekas, tong sampah dari tutup botol bekas, produk 3D pencemaran lingkungan dari barang bekas.

Instrumen yang digunakan, yaitu lembar observasi penilaian kreativitas produk dengan aspek penilaian, yaitu kebaruan (novelty), keluwesan (flexibility), dan kerincian (elaboration). Instrumen Peer Assesment berupa lembar observasi yang digunakan untuk menilai kinerja antar teman dengan aspek penilian terdiri atas kerjasama, keaktifan membuat produk, kemunculan ide. Adapun angket digunkan untuk mengidentifikasi respons siswa terhadap penggunaan metode Gallery Walk. Analisis data kreativitas siswa menggunakan uji statistik nonparametrik Wilcoxon.

\section{HASIL DAN PEMBAHASAN Hasil}

Pada Gambar 1. Ditunjukkan data penilaian berdasarkan lembar observasi penilaian kreativitas produk antara kelas eksperimen dan kelas kontrol.

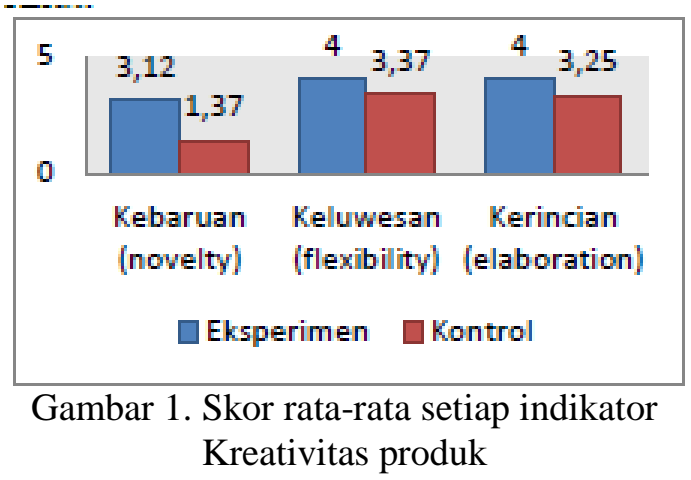

Berdasarkan skor dapat dilihat bahwa pada kelas eksperimen lebih unggul dibandingkan kelas kontrol. Dengan skor rata-rata 2,78 (kreatif) untuk kelas ekspeimen dan skor ratarata 2,37 (cukup kreatif) untuk kelas kontrol. Selanjutnya, data tersebut dianalisis menggunakan Uji Wilcoxcon. Hasil uji tersebut dapat dilihat pada Tabel 2 . 
Tabel 2. Kreativitas Produk Hasil Uji Wilcoxon

\begin{tabular}{ccc}
\hline Hipotesis & $\mathrm{R}^{\#}$ & $\mathrm{Z}$ \\
\hline Terdapat pengaruh metode & 820 & 7,7 \\
$\begin{array}{c}\text { Gallery Walk terhadap kreativitas } \\
\text { siswa dikelas X SMA Negeri 1 } \\
\text { Gegesik }\end{array}$ & \\
\hline
\end{tabular}

Berdasarkan Tabel 2. hasil uji wilcoxon diperoleh $\mathrm{R}^{\#} 820>\mathrm{Z}$ 7,7 dimana $\mathrm{H}_{0}$ ditolak dan $\mathrm{H}_{1}$ diterima yang berarti bahwa ada pengaruh nilai kreativitas antara kelas yang menggunakan metode Gallery Walk dengan kelas yang tidak menggunakan metode Gallery Walk. Pada penelitian ini juga dibantu dengan penggunaan Peer Assesment, hasil Peer Assesment tersebut dapat dilihat pada Tabel 3.

Tabel 3. Hasil Peer Assesment

\begin{tabular}{ccccc}
\hline & & \multicolumn{3}{c}{$\begin{array}{c}\text { Persentase rata-rata indicator peer } \\
\text { assessment }(\%)\end{array}$} \\
\cline { 3 - 5 } Kelas & $\mathrm{N}$ & Kerjasama & $\begin{array}{c}\text { Keaktifan } \\
\text { membuat } \\
\text { produk }\end{array}$ & $\begin{array}{c}\text { Kemuncu } \\
\text { lan ide }\end{array}$ \\
\hline Eksperimen & 40 & 100 & 100 & 100 \\
Kontrol & 40 & 83 & 81 & 83 \\
\hline
\end{tabular}

Hasil dari Peer assesment menunjukkan nilai yang baik dalam semua indikator hal ini menunjukkan bahwa tingkat kerjasama dalam kemunculan ide dan keaktifan membuat produk pun baik. Kemudian dalam penelitian ini juga dibantu dengan angket respon siswa terhadap penggunaan metode Gallery Walk. Hasil angket ini dapat dilihat pada Tabel 4.

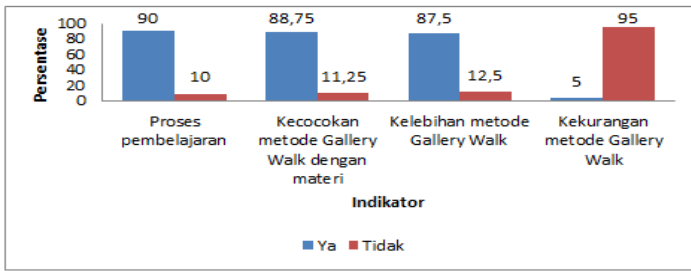

Gambar 2. Hasil Angket

Angket respon siswa diketahui bahwa siswa memberikan respon yang baik terhadap penerapan metode Gallery Walk dengan rincian presentasi $90 \%$ untuk proses pembelajaran, 88,75\% untuk kecocokan Metode Galley Walk terhadap materi, $87,5 \%$ untuk kelebihan metode Gallery Walk, 5\% untuk kekurangan metode Gallery Walk.

\section{Pembahasan}

Berdasarkan hasil uji hipotesis pada tabel 4.2 diperoleh $R^{\#} 820>Z$ 7,7 yang menunjukkan bahwa adanya pengaruh metode Gallery Walk terhadap kreativitas siswa pada materi pencemaran lingkungan kelas X di SMA Negeri
1 Gegesik. Gallery Walk berpengaruh terhadap kreativitas siswa karena Metode Gallery Walk ini memberikan kesempatan kepada siswa untuk berkarya atau membuat karya sesuai pemahaman terhadap suatu permasalahan yang didiskusikan kemudian diwujudkan dalam bentuk karya yang kemudian dipamerkan. Metode Gallery Walk menuntut siswa untuk aktif dalam proses pembelajaran, kreatif dalam membuat suatu produk, karya, gagasan, gambar maupun skema sesuai hal-hal apa yang ditemukan atau diperoleh pada saat diskusi kelompok untuk dipamerkan. Hal tersebut, senada dengan pendapat Budiharto (2010:53) yang menyatakan bahwa metode Gallery Walk melibatkan siswa secara langsung dalam kegiatan pemecahan masalah, dapat menumbuhkan motivasi belajar, menumbuhkan kreativitas siswa, mengaktifkan proses pembelajaran, menjadikan peserta didik kreatif dan inovatif serta menciptakan pembelajaran yang menyenangkan. Diketahui pada kelas eksperimen siswa berpendapat bahwa proses pembelajaran yang dilakukan sangat efektif dilakukan untuk mengembangkan kreativitas, oleh karena itu metode Gallery Walk sesuai diterapkan untuk mengembangkan kreativitas siswa.

Disamping itu, metode Gallery Walk juga mendukung terhadap pekembangan kreativitas siswa. Hal ini tercermin pada setiap langkah metode pembelajaran Gallery Walk, yaitu pada langkah pertama siswa disajikan beberapa permasalahan tentang penyebab dan dampak yang terjadi akibat pencemaran lingkungan, pada langkah ini dapat memicu rasa ingin tahu siswa dalam memecahkan masalah dan memberikan solusi terhadap permasalahan tersebut. Kemudian, pada langkah keenam yaitu perancangan pembuatan produk yang akan dibuat dari menentukan topik atau tema pembuatan produk dari permasalahan yang telah disajikan oleh guru, menentukan alat dan bahan yang akan digunakan dan menentukan cara kerja. Langkah keenam ini melatih siswa dalam kebaruan (novelty) yaitu siswa mampu membuat produk baru ataupun hasil inovasi baik dari segi bentuk, bahan, fungsi dengan memanfaatkan bahan-bahan yang sudah tidak terpakai.

Proses pembuatan produk juga melatih siswa dalam keluwesan (flexibility),. Hal ini terbukti hasil produk pada kelas eksperimen menunjukkan bahwa siswa pada kelas eksperimen mampu memilih alat dan bahan yang mudah didapat dari bahan-bahan bekas atau yang sudah tidak terpakai seperti koran bekas, 
sterofom bekas, kayu bekas, pita bekas, kardus bekas, tempat rokok bekas, kertas bekas, tali bekas, botol minuman bekas, tutup botol minuman, gagang es krim. Selain dapat memilih alat dan bahan yang mudah didapat, semua kelompok juga mampu menulis cara penggunaan alat dan bahan yang telah didapat. Selanjutnya, dalam proses pembuatan produk juga melatih kerincian (elaboration), yang dibuktikan berdasarkan hasil produk yang telah dibuat oleh semua kelompok. Produk yang dibuat disajikan secara terperinci, yaitu semua kelompok menulis judul produk, menulis cara kerja pembuatan produk, menulis keterangan produk dengan lengkap yaitu adanya keterangan penyebab, dampak dan cara mengatasi pencemaran lingkungan.

Penilaian kreativitas produk juga dibantu dengan peer assesment dengan indikator kerjasama, keaktifan membuat produk dan kemunculan ide. Nilai peer assesment antara kelas kontrol dan kelas eksperimen memiliki persentase yang berbeda. Pada kelas eksperimen seluruh indikator memiliki persentase $100 \%$ hal ini menujukkan bahwa nilai peer assesment yang baik maka tingkat kerjasama dalam kemunculan ide dan keaktifan membuat produk pun baik. Pengaruh peer assesment, yaitu mengontrol/mereview antar sesama teman, dan merasa pekerjaannya dihargai. Hal ini terbukti dalam proses pembelajaran siswa saling menegur, saling memberi masukan dalam proses pembelajaran sehingga proses pembelajaran lebih aktif, lebih inovatif, dan lebih merangsang daya kreatif siswa. Hal tersebut senada dengan penelitian Yunianta (2012), dalam penelitian beliau peer assesment merupakan salah satu langkah yang dapat membantu meningkatkan keaktifan siswa.

Berdasarkan pemaparan diatas, terlihat jelas bahwa metode Gallery Walk dapat berpengaruh terhadap kreativitas siswa, karena selain metode pembelajaran yang aktif, kreatif dan menyenangkan, juga menuntut siswa untuk menumbuhkan kreativitas siswa melalui pembuatan produk. Respon siswa dalam penerapan metode Gallery Walk ini sangat baik yang dibuktikan dengan hasil Peer Assesment dan hasil produk yang dibuat oleh setiap kelompok.

\section{SIMPULAN}

Berdasarkan hasil penelitian dan pembahasan, maka dapat disimpulkan: 1) Terdapat pengaruh antara metode Galley Walk terhadap kreativitas siswa, 2) Hasil penelitian kreativitas pada kelas eksperimen rata-rata skor yaitu 2,78 dari 40 siswa yang menunjukkan termasuk kedalam kriteria kreatif dan pada kelas kontrol rata-rata skor yaitu 2,37 dari 40 siswa yang menunjukkan termasuk kedalam kriteria cukup kreatif; 3) Nilai Peer assesment yang baik menunjukkan bahwa tingkat kerjasama dalam kemunculan ide dan keaktifan membuat produk pun baik; 4) Angket respons siswa diketahui bahwa siswa memberikan respon yang baik terhadap penerapan metode Gallery Walk.

\section{REFERENSI}

Ali, M dan Asrori, M.2012.PSIKOLOGI REMAJA Perkembangan Peserta Didik.Jakarta:PT Bumi Aksara

Badan Standar Nasional Pendidikan No.VI Tahun 2006 Tentang Standar Kompetensi Lulusan (online). Tersedia: http://bsnp-indonesia.org [diakses 03 Maret 2017]

Budiharto, A.A. 2010. Problematika Implementasi Metode Gallery Walk dalam Pembelajaran Biologi Materi Pokok Virus Kelas $X$ di SMA ISLAMIYAH AT-TANWIR TALUN SUMBERREJO BOJONEGORO Tahun 2010/2011 (online). Tersedia: http://library.walisongo.ac.id/digilib/files /disk1/124/jtptiain - gdl alarifbudih6188-1-skripsi-p.pdf [diakses 17 April 2017]

Fathurrohman, M. 2015. Model-Model Pembelajaran Inovatif. Jogjakarta : ArRuzz Media

Haryono. 2013. Pembelajaran IPA yang Menarik dan Mengasyikan : Teori dan Aplikasi PAIKEM. Yogyakarta : Kepel Press

Persada, R.A. 2015. Pengembangan Satuan Acara Perkuliahan (SAP) Pemrograman Linier Berkarakter dengan penerapan Metode Gallery Walk untuk Meningkatkan Kreativitas Mahasiswa (online). Tersedia https://webcache.googleusercontent.com /search?q=cache:kMWMIY8YvncJ:https ://syekhnurjati.ac.id/jurnal/index.php/ed 
Quagga: Jurnal Pendidikan dan Biologi

Volume 10, Nomor 2, Juli 2018

uma/article/download/18/17+\&cd=1\&hl $=e n \& c t=c l n k$ [diakses 10 Februari 2017]

Tim Teaching.Pendidikan Pelatihan Profesi Guru (PLPG) LPTK Rayon IAIN Walisongo Semarang.

Tersedia:http://www.scribd.com/doc/416 37080/6-aplikasi-PAIKEM-revisi [diakses 11 Februari 2017]

Undang-Undang Republik Indonesia No.20 Tahun 2003 Tentang Sistem Pendidikan Nasional. Solo"Giri Ilmu

Yunianta, T. N. H. 2012. Kemampuan berpikir kreatif siswa pada implementasi project-based learning dengan peer and self-assessment untuk materi segiempat kelas vii smpn rsbi 1 juwana di kabupaten pati (online). Tersedia: http://eprints.uny.ac.id/10107/1/P\%20\%2095.pdf [diakses 10 Juli 2017]
p-ISSN 1907-3089, e-ISSN2651-5869

https://journal.uniku.ac.id/index.php/quagga 